Article

\title{
Energy, Economic, and Environmental Performance of a Single-Family House in Chile Built to Passivhaus Standard
}

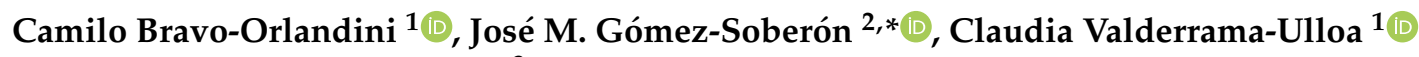 \\ and Francisco Sanhueza-Durán ${ }^{3}$ \\ 1 School of Civil Construction, Faculty of Engineering, Pontificia Universidad Católica de Chile, \\ Vicuña Mackenna 4680, Macul 78100000, Chile; cbbravo2@uc.cl (C.B.-O.); c.valderrama@uc.cl (C.V.-U.) \\ 2 Higher Polytechnic School of Building of Barcelona, Polytechnic University of Catalonia, \\ Doctor Marañón Avenue 44-50, 08028 Barcelona, Spain \\ 3 Escuela de Ingeniería en Construcción, Facultad de Ciencias, Universidad Mayor, Avenida Portugal 351, \\ Santiago 8330231, Chile; francisco.sanhueza@umayor.cl \\ * Correspondence: josemanuel.gomez@upc.edu; Tel.: +34-934-016-242
}

Citation: Bravo-Orlandini, C.;

Gómez-Soberón, J.M.;

Valderrama-Ulloa, C.;

Sanhueza-Durán, F. Energy,

Economic, and Environmental

Performance of a Single-Family

House in Chile Built to Passivhaus

Standard. Sustainability 2021, 13, 1199.

https://doi.org/10.3390/su13031199

Academic Editor: Dušan Katunský

Received: 27 November 2020

Accepted: 13 January 2021

Published: 24 January 2021

Publisher's Note: MDPI stays neutral with regard to jurisdictional claims in published maps and institutional affiliations.

Copyright: (c) 2021 by the authors. Licensee MDPI, Basel, Switzerland. This article is an open access article distributed under the terms and conditions of the Creative Commons Attribution (CC BY) license (https:// creativecommons.org/licenses/by/ $4.0 /)$.

\begin{abstract}
The energy consumption of buildings accounts for $22 \%$ of total global energy use and $13 \%$ of global greenhouse gas emissions. In this context, this study aims to evaluate the energy, economic, and environmental performance of housing in Chile built according to the Passivhaus (PH) standard. The standard was applied to housing in eight representative climate zones with a single-family residence as reference. The analysis incorporated passive strategies, which are considered as pillars of the PH. The energy performance was analyzed using the Passive House Planning Package software (PHPP), version 9.6a. The results showed that when every passive strategy is implemented, the heating energy demand decreases by $93 \%$, while the refrigeration demand is nonexistent. These results were achieved through a $37 \%$ increase in the overall initial budget investment, which will be amortized over an 11-year period. In this way, the primary energy consumption is reduced by $32 \%$ and, correspondingly, $\mathrm{CO}_{2}$ emissions are reduced by 39\%. In modern Chile, it is difficult (but not impossible) to incorporate $\mathrm{PH}$. However, governmental programs and aids could represent an initial step. Therefore, this research will help to identify strategies for incorporating PH in Chile, with the aim of improving the energy performance of housing.
\end{abstract}

Keywords: energy consumption; Passivhaus; single-family housing; passive strategies; Passive House Planning Package; primary energy

\section{Introduction}

The human influence on climate conditions is evident, resulting in anthropogenic greenhouse gas emissions reaching their highest recorded values in history.

Greenhouse gas emission projections vary greatly depending on both the level of socioeconomic development and the climate policies implemented in each country [1].

The construction sector is responsible for over one-third of the total global energy consumption and almost $40 \%$ of the total $\mathrm{CO}_{2}$ emissions (both direct and indirect). Furthermore, the energy demand of buildings and building construction is on the rise due to countries having improved access to energy, both increased ownership and use of electronic devices, and the fast growth of the construction sector [2,3].

The energy used for heating, refrigeration, domestic hot water, and lighting represents the highest total energy percentage in the different stages of a building's lifespan, being collectively responsible for $22 \%$ of the total global energy consumption and approximately $13 \%$ of global GHG emissions [4]. This type of consumption typically ranks first as the largest source of $\mathrm{CO}_{2}$ emissions, surpassing the energy necessary to extract and manufacture materials, and even the energy necessary for the construction of buildings [5]. 
Residential buildings are responsible for two-thirds of emissions of this type. Incidentally, these buildings have the highest potential for energy savings [6].

The importance of the construction sector in Chile is evident. This sector is responsible for $26 \%$ of the total energy use, $34 \%$ of solid waste production, $33 \%$ of GHG emissions, and $6 \%$ of water use [7]. Furthermore, residential construction in Chile accounts for a quarter of the total energy consumption [8]. In the future, buildings must be more energy efficient in order to address the issue of excessive energy consumption and reduce these figures [9].

Worldwide, there are voluntary environmental certifications and building standards that can be adopted by the construction sector toward mitigating the negative effects of climate change. These certifications and standards go one step further than the national building regulations. Environmental certifications are designed to quantify and control sustainability indexes in construction through different ISO (International Organization for Standardization) regulations. The LEED (Leadership in Energy and Environmental Design) - developed by the U.S. green building council (USGBC), in line with American regulations-is the most well-known ISO regulation. A LEED-certified building does not necessarily use less energy than a building without this certification, which consequently leaves the energy consumption issue unresolved. Moreover, it has been found that the energy performance measured in LEED buildings has little correlation to the building's certification level or the number of energy credits the building has achieved in the design stage $[9,10]$.

From a regulatory point of view, although Chile has a thermal regulation policy [11] that regulates the requirements for the envelope, restricting the transmittance values in ventilated walls, ceilings, and floors, there is no regulatory reference aimed at reducing the demand for energy or regarding the airtightness of a house. Similarly, Brazil-a country that has regulations that are mainly oriented toward the levels of transmittance of certain elements from the envelope-is comparable to Chile in that it has not implemented regulations that establish requirements regarding energy demand levels [12]. Concurrently, the thermal transmittance values of an enclosure are regulated in Chile while taking into consideration its climatic and performance similarities with other European countries, such as the United Kingdom or Spain. Additionally, when considering levels of hermeticity, establishing a limit on the energy demand may still be insufficient [13-17], as is the case in countries such as Sweden and Portugal, where the imposition of regulations on the transmittance levels of the envelope-as in the previous examples-failed to substantially reduce the energy demand of the dwellings $[12,18]$. As a policy to mitigate these gaps, the European Union, through its Directive 2010/31/EU, stipulates that from the year 2021, houses should be built with near-zero energy consumption restrictions in place [19]. On the other hand, building standards focus on controlling issues that are very influential with regard to sustainability, such as energy use and consumption during a building's lifespan. Passivhaus (PH) is the best known international standard, as its required energy efficiency is higher than that of any other comparable standard [20]. It was developed in Germany in the late 1980s by Wolfgang Feist and Bo Adamson. PH ensures a comfortable indoor climate in the summer and winter without a conventional heating distribution system. In this way, the energy required for heating is reduced by approximately $80 \%$, and the general primary energy consumption is reduced by $50 \%$ (including utilities and electric appliances). To meet these targets, the building's heating load must not exceed $10 \mathrm{~W} / \mathrm{m}^{2}[21,22]$, which can be achieved by an additional $5-10 \%[23,24]$ cost expenditure.

The adoption of $\mathrm{PH}$ in Chile is relatively recent. The first PH-certified building was built in 2010 [25]. Additionally, two more buildings in Chile are recognized by the Passive House Institute (PHI), though without certification [26].

Regardless of the Chilean regulation, different studies identify Passivhaus as an aggressive and demanding standard [27], and it has even been considered the most aggressive in the world [28]. To achieve this standard, extra effort must be made, as in the Australian case, where the use of Passivhaus as a design tool allowed the design team to overcome limitations of the Australian building code [29]. Therefore, it is necessary to evaluate 
different strategies according to the climate in order to achieve PH. In tropical climates, the main strategy entails cooling and dehumidification [30]; in China, the use of an mechanical ventilation with heat recovery (MVHR) system is essential [31], and for all types of climates in Germany, Romania, and Ukraine, energy demand increases as latitude increases, so this strategy aims to increase insulation levels based on location [32]. On the other hand, studies show that to achieve $\mathrm{PH}$, it is necessary to place special emphasis on summer overheating and on shading strategies to achieve thermal comfort [33].

Given the outlined context, this study suggests incorporating the PH standard for housing in Chile through the addition of building construction improvements for housing situated across the country and reflecting various climates. Likewise, it evaluates whether or not $\mathrm{PH}$ is a good strategy at the national level in terms of energy savings, necessary investments, and environmental externalities. At the same time, the goal is to promote a concrete methodology to fight climate change. For this purpose, the 9.6a version of the energy balance tool Passive House Planning Package (PHPP) was used [34]. As a part of the certification process, it is mandatory that each $\mathrm{PH}$ housing development be modeled and verified with PHPP [35].

\section{Materials and Methods}

The methodology applied in this research can be divided into five stages (Figure 1): (i) the Passivhaus standard context, where the requirements of the standard are explained; (ii) the building context in Chile; (iii) the description of housing under study; (iv) the presentation of the representative climate zones considered; and (iv) the simulation of the house using PHPP software.
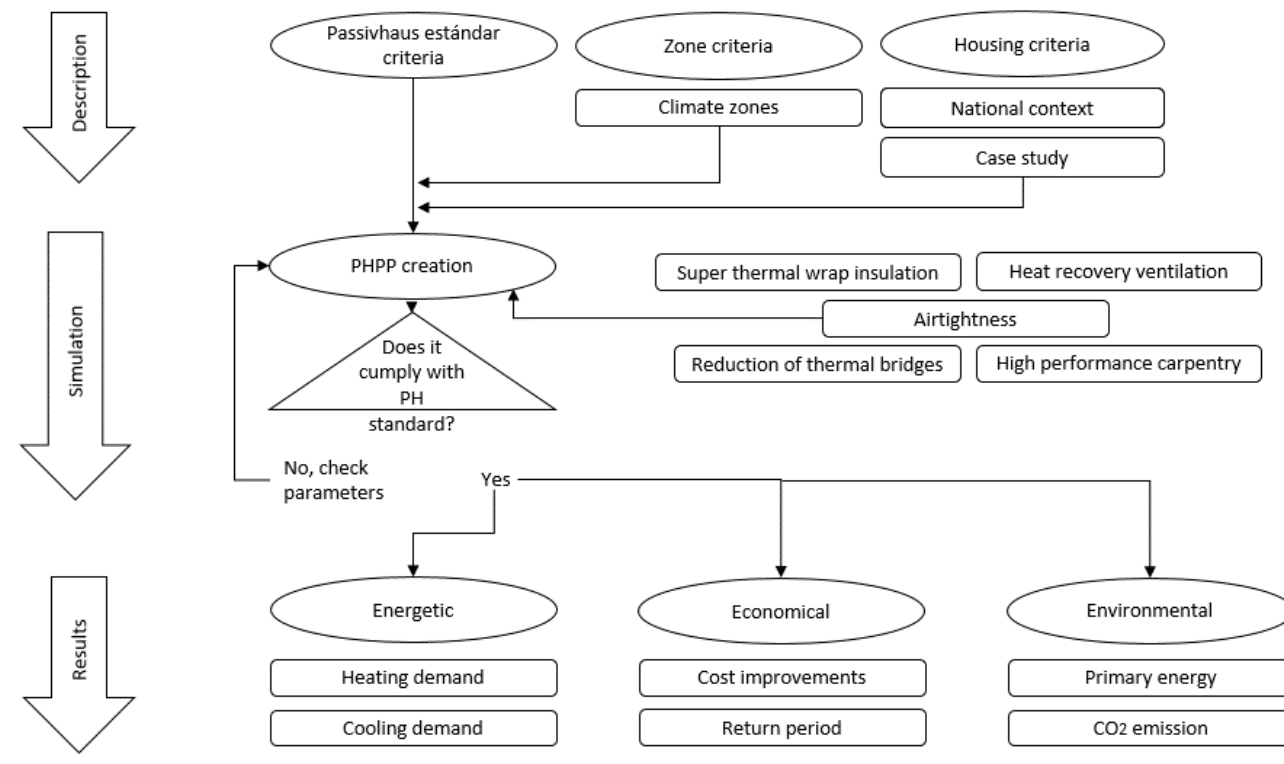

Figure 1. Methodology.

\subsection{Passivhaus Standard}

Passivhaus buildings minimize heat flow through the building's envelope and, therefore, combine high thermal comfort, extremely low energy demand, and a relatively low lifespan cost. The operational costs are low since improved enclosure performance leads to a smaller, mechanical service system required to maintain comfort. In general, the maximum heating or refrigeration load is lower than $10 \mathrm{~W} / \mathrm{m}^{2}$ of the living area [24]. These types of constructions can be built almost anywhere in the world, from the Arctic to Scandinavia and the Mediterranean, where concepts allow for the provision of buildings with similar interior qualities and equivalent energy demands without impacting the architect's design freedom [20]. 
A building must comply with specific criteria to obtain PH certification (Table 1) [36], for example, having maximum values of $15 \mathrm{kWh} / \mathrm{m}^{2}$ per year (equivalent to $10 \mathrm{~W} / \mathrm{m}^{2}$ of power) for heating/refrigeration demand. Likewise, the primary energy demand must be equal to or lower than $120 \mathrm{kWh} / \mathrm{m}^{2}$ per year. The airtightness level must be equal to or lower than 0.6 air changes per hour for pressurization and de-pressurization at $50 \mathrm{~Pa}$ pressure, and thermal comfort should allow for only $10 \%$ of annual hours above $25^{\circ} \mathrm{C}$. Primary energy consumption refers to the amount of demand for the site's primary energy and the losses that occur during generation, transmission, and energy distribution [20].

Table 1. Passivhaus (PH) standard criteria.

\begin{tabular}{cc}
\hline Description & Values \\
\hline Heating/Refrigeration Demand & $<15 \mathrm{kWh} / \mathrm{m}^{2}$ a or $10 \mathrm{~W} / \mathrm{m}^{2}$ of power \\
Primary Energy Demand & $<120 \mathrm{kWh} / \mathrm{m}^{2} \mathrm{a}$ \\
Airtightness & $<0.6 \mathrm{~h}^{-1}$ a $50 \mathrm{~Pa}$ \\
Thermal Comfort & $<10 \%$ of hours over $25^{\circ} \mathrm{C}$ \\
\hline
\end{tabular}

\subsection{Building Context in Chile}

The housing sector in Chile is regulated by the General Construction and Urbanism Ordinance (OGUC) [11]. This ordinance sets the maximum value for thermal transmittance (U value) for envelope elements in new constructions. The OGUC's 2007 update restricts the $U$ value for walls, roofs, suspended floors, and glazed areas. However, it leaves out several unsolved regulations regarding the building's energy development, such as the risk of overheating and infiltrations, among others. These regulatory shortcomings are more evident when national regulations are compared to international regulations; for example, the Spanish Technical Building Code (CTE) [14]. The CTE has similar features to the Chilean regulation as they share several climate types. When comparing these two norms, it is possible to identify differences (Table 2) that directly affect energy demand [8,37] —for example, more explicit specifications regarding carpentry or climate zones for simulations.

Table 2. Regulatory differences between Chile and Spain.

\begin{tabular}{ccc}
\hline Description & Chilean Thermal Regulation & Spanish Technical Building Code (CTE) \\
\hline Regulation Scope & Exclusive to housing & Construction sector \\
Glass & Relation between type and maximum glazed area & Climate zone, orientation, and solar factor \\
Contemplated & Contemplated \\
Specifications for Carpentry & Not contemplated & 12 \\
U value for flooring & Not contemplated, only suspended floor & 7 \\
Number of Zones & & \\
\hline
\end{tabular}

Since Chile has more diverse climate variability than Spain, it should have a broader climate zone classification. On the other hand, Chilean regulations do not restrict infiltration levels, with the national average being $12.9 \mathrm{~h}^{-1}$ [7], differing vastly from the regulated 0.3 air changes per hour in European countries like Germany, Austria, Belgium, Slovenia, Lithuania, and Norway, among others [38].

Given this context, $86 \%$ of Chile's housing built before 2000 does not have any kind of insulation. Between 2001 and 2006, 12\% of built housing only had roof insulation. Lastly, only 2\% of houses built between 2007 and 2015 comply with the current thermal regulations [39].

Regarding building materials, concrete is predominantly used in the north of Chile, masonry in the center, and wood in the south [40]. There are similar architectural typologies throughout the country.

Based on this scenario, and attempting to mitigate climate change, Chile has committed itself to reducing its GHG emissions by at least $30 \%$ by 2030 based on its emissions in 2007 [41]. The construction sector's guidelines state that construction should be accomplished efficiently, minimize energy requirements by at least $30 \%$, and minimize 
environmental externalities in reaching the appropriate comfort levels. The successful implementation of $\mathrm{PH}$ would mean achieving these goals.

\subsection{Description of Housing under Study}

The study is based on housing that is in compliance with the identification of building parameters, as described in official reports (typology, materials, area, and infiltrations) [7,42-44], which represents the majority of the housing stock in Chile (Table 3).

Table 3. Features of the housing under study.

\begin{tabular}{cc}
\hline Features & Detail \\
\hline Type of Housing & House \\
External Wall Material & Masonry \\
Floor Material & Wood parquet \\
Roof Material & Fiber cement \\
$\mathrm{N}^{\circ}$ of People & 3 \\
$\mathrm{~N}^{\circ}$ of Bedrooms & 2 \\
Housing Investment & Private \\
Type of Investment & Nonsubsidized real estate \\
Area (m ${ }^{2}$ ) & 81.72 \\
Infiltrations n50 & 11.8 \\
\hline
\end{tabular}

Given this context, the research focuses on single-family masonry housing, with concrete pillars and beams of $81.72 \mathrm{~m}^{2}$, two bedrooms, two bathrooms, one living room, one dining room, one kitchen, and a laundry area (Figure 2A), designed for three people. This type of housing has foundation walls that are $500 \mathrm{~mm}$ high by $400 \mathrm{~mm}$ wide, with $400 \mathrm{~mm}$ high by $200 \mathrm{~mm}$ wide footings. The external wall is made of $140 \mathrm{~mm}$ thick brick masonry. The roof contains galvanized steel trusses covered by asphalt roof tiles. The interior roof structure contains $60 \mathrm{~mm}$ mineral wool panels and, underneath, plasterboard, leaving an unventilated space. The floor consists of a $70 \mathrm{~mm}$ concrete floor slab with a $10 \mathrm{~mm}$ wood parquet. The windows are single-glazed and have an aluminum frame with no thermal bridge break.
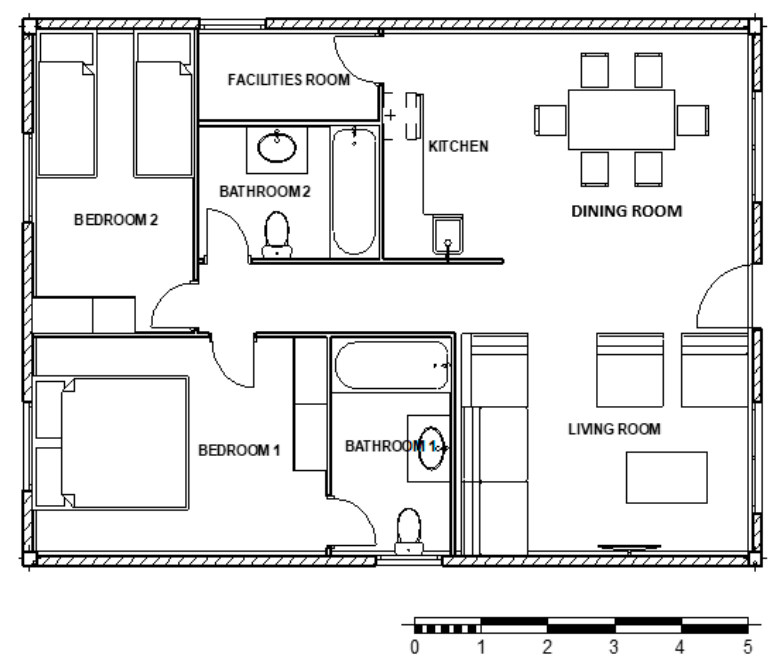

(a)

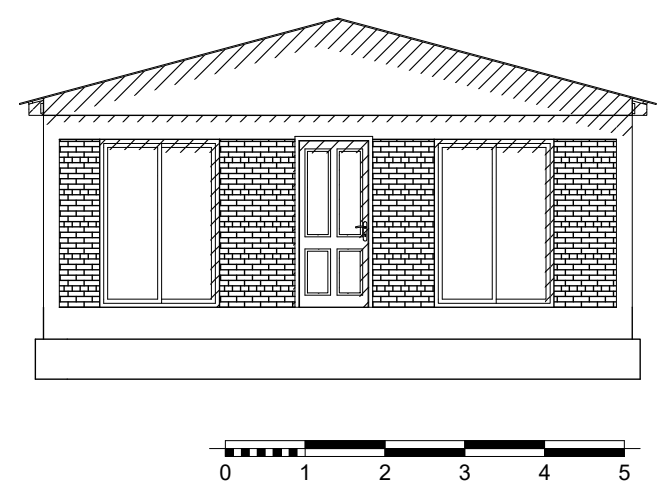

(b)

Figure 2. The housing under study: floor plan (a) and east façade (b).

These characteristics were selected from conventional construction systems certified by current national thermal regulations [45-47] because each new innovative construction system that is to be used in Chile must go through a certification process. Therefore, these 
characteristics were chosen in order to comply with the energy performance of Passivhaus, increase the thickness of insulation, or use constructive solutions present in the regulations. Moreover, it should be noted that the PHPP software only takes into account traditional construction solutions.

According to the identified features, the areas of the non-glazed and glazed envelope are obtained (Figure $2 b$ ) as well as the air volume used to ventilate these areas (Table 4). These values correspond to the areas inputted in the PHPP software. These areas are essential as they are in contact with the outside environment. The entrance door is included in the glazed area.

Table 4. Key building details for the housing under study.

\begin{tabular}{|c|c|}
\hline Description & Values \\
\hline Referential Energy Area & $75.85 \mathrm{~m}^{2}$ \\
\hline Ventilated Volume & $182.00 \mathrm{~m}^{3}$ \\
\hline External Wall Area & $75.10 \mathrm{~m}^{2}$ \\
\hline Roof Area & $89.92 \mathrm{~m}^{2}$ \\
\hline Concrete Slab Area & $81.72 \mathrm{~m}^{2}$ \\
\hline Window Area (S/W/N/E) & $13.78 \mathrm{~m}^{2}(1.22 / 2.88 / 1.20 / 8.50)$ \\
\hline Thermal Envelope Total & $260.52 \mathrm{~m}^{2}$ \\
\hline
\end{tabular}

Furthermore, through these materials, it is possible to obtain values for the conductivity and thermal transmittance of the building elements (Table 5). Thickness and conductivity values were obtained for the different building solutions identified throughout the country [45].

Table 5. Thermal envelope features.

\begin{tabular}{|c|c|c|c|c|}
\hline Building Element & Material & Thickness (mm) & Conductivity (W/mK) & $\begin{array}{c}\text { Transmittance } \\
\left(\mathrm{W} / \mathrm{m}^{2} \mathrm{~K}\right)\end{array}$ \\
\hline Wall & Reinforced Masonry Brick & 140 & 0.26 & 1.49 \\
\hline \multirow[b]{2}{*}{ Roof } & Drywall & 10 & 0.26 & \multirow[b]{2}{*}{0.74} \\
\hline & Mineral Wool & 60 & 0.04 & \\
\hline \multirow[b]{2}{*}{ Ground Floor } & Parquet & 10 & 1.30 & \multirow{2}{*}{3.45} \\
\hline & Concrete & 70 & 1.63 & \\
\hline \multirow[b]{2}{*}{ Window } & Single Glazing & 4 & - & 5.80 \\
\hline & $\begin{array}{l}\text { Aluminum Frame (no Break of } \\
\text { Thermal Bridge, BTB) }\end{array}$ & 90 & - & 5.70 \\
\hline \multirow{2}{*}{ Door } & Wood Slab & 80 & - & 2.00 \\
\hline & Wood Frame & 124 & - & 1.04 \\
\hline
\end{tabular}

Regarding facilities, the housing under study does not contain heating systems. For domestic hot water, a $15 \mathrm{~kW}$ nominal power gas boiler was considered.

In Chile's southern cities, the most used fuel in the residential sector is biomass, at $38 \%$ of the total. On the other hand, cities in the center and north use more electricity in residences at $38 \%$ of the total [48]. Biomass and electricity inflation percentages in Chile are $3.9 \%$ and $2.4 \%$, respectively $[49,50]$.

\subsection{Climate Zones}

Chile has various landforms, including the Andes range, the Coast range, and the Pacific Ocean. Thanks to this particular configuration, there is broad climate variability, ranging from extremely hot and arid areas in the north to the glaciated areas and ice fields of the south.

This study identifies representative climate zones in the territory using the nine climate zones defined in the National Institute of Standardization of Chile (NCh) 1079-2008 [51]. This code includes the highest number of climate parameters in the country, more than the 
Thermal Regulation (RT) policy [52]. While the RT divides thermal zones based on only one meteorological variable (heating degree days), it does not consider the location's thermal oscillations between day and night. NCh 1079-2008 is based on meteorological variables that define a type of climate. These variables are average temperature, daily temperature oscillation, sun exposure, relative humidity, cloud cover, rain, prevailing winds, ice, snow, salinity, and altitude.

It is necessary to define the cities for simulation of each climate zone and the parameters by which these cities will be selected. In this context, PH reduces energy consumption and improves indoor air quality, making it an excellent alternative for cities with poor air quality indexes. Based on this premise, this study chose the most polluted cities in each thermal zone [53], leaving the Andean zone out due to its climate harshness not complying with habitability requirements. In this way, the eight cities for research are defined (Table 6): Calama, Copiapó, La Serena, Viña del Mar, Santiago, Temuco, Valdivia, and Coyhaique.

Table 6. General data of the cities studied.

\begin{tabular}{cccc}
\hline City & Thermal Zone & $\begin{array}{c}\text { Fine Particulate Matter } \\
\text { Concentration }(\mu \mathrm{g} / \mathrm{m})\end{array}$ & Latitude \\
\hline 1-Calama & Northern Desert & 15 & $22^{\circ} 27^{\prime} \mathrm{S}$ \\
2-Copiapó & Northern Transversal Valley & 14 & $27^{\circ} 22^{\prime} \mathrm{S}$ \\
3-La Serena & Northern Coastline & 15 & $29^{\circ} 54^{\prime} \mathrm{S}$ \\
4-Viña del Mar & Central Coastline & 15 & $33^{\circ} 01^{\prime} \mathrm{S}$ \\
5-Santiago & Central Interior & 33 & $33^{\circ} 27^{\prime} \mathrm{S}$ \\
6-Temuco & Southern Interior & 46 & $38^{\circ} 44^{\prime} \mathrm{S}$ \\
7-Valdivia & Southern Coastline & 37 & $39^{\circ} 48^{\prime} \mathrm{S}$ \\
8-Coyhaique & Far South & 56 & $45^{\circ} 57^{\prime} \mathrm{S}$ \\
\hline
\end{tabular}

Source: $[51,53,54]$.

\section{Data Input}

In the second stage of the research (where housing is taken from its current state to $\mathrm{PH}$ standards), the thermal envelope features must be improved (Table 7) by incorporating continuous insulation on every element, adding double-glazed windows in Calama, Copiapó, and La Serena, and triple-glazed windows in Viña del Mar, Santiago, Temuco, Valdivia, and Coyhaique. Furthermore, a controlled ventilation machine with a heat recovery rate of $81 \%$ is considered, as well as an airtightness plate, ensuring an n50 value of $0.6 \mathrm{~h}^{-1}$. For Coyhaique, a PH-certified door is implemented due to climate harshness. Lastly, thermal bridges are reduced to $0.01 \mathrm{~W} / \mathrm{mK}$ at conflictive points in every city.

Table 7. New maximum value for thermal transmittance (U value; $\mathrm{W} / \mathrm{m}^{2} \mathrm{~K}$ ).

\begin{tabular}{cccccc}
\hline City & Ground Floor & Exterior Walls & Roof & Windows & Door \\
\hline Calama & 0.32 & 0.21 & 0.27 & 2.01 & 2.00 \\
Copiapó & 0.26 & 0.21 & 0.28 & 2.01 & 2.00 \\
La Serena & 0.51 & 0.31 & 0.39 & 2.01 & 2.00 \\
Viña del Mar & 0.68 & 0.33 & 0.28 & 0.73 & 2.00 \\
Santiago & 0.26 & 0.19 & 0.28 & 0.73 & 2.00 \\
Temuco & 0.20 & 0.17 & 0.20 & 0.73 & 2.00 \\
Valdivia & 0.20 & 0.17 & 0.22 & 0.73 & 2.00 \\
Coyhaique & 0.08 & 0.08 & 0.10 & 0.73 & 0.81 \\
\hline
\end{tabular}

\section{Results}

The evaluation of the results is based on the incorporation of five "building improvements": thermal insulation, free construction of thermal bridges, airtightness, controlled ventilation machines with heat recovery, and high-performance carpentry. 


\subsection{Energy Analysis}

Once building improvement data were inputted to the PHPP, an energy comparison between the housing under study in each city and the PH housing was carried out. Figure 3 shows the heating demand results. The country average is $300.2 \mathrm{kWh} / \mathrm{m}^{2}$ per year. The country's average heating saving is $93 \%$ after incorporating PH into housing. In terms of refrigeration, it is not necessary to implement active elements to cool indoor air. Since the indoor temperature does not exceed $10 \%$ of temperatures over $25^{\circ} \mathrm{C}$, there is no overheating and no refrigeration demand as the controlled ventilation machine with heating recovery is responsible for this. This study considered the machine as a passive element as it requires a small amount of energy to operate.

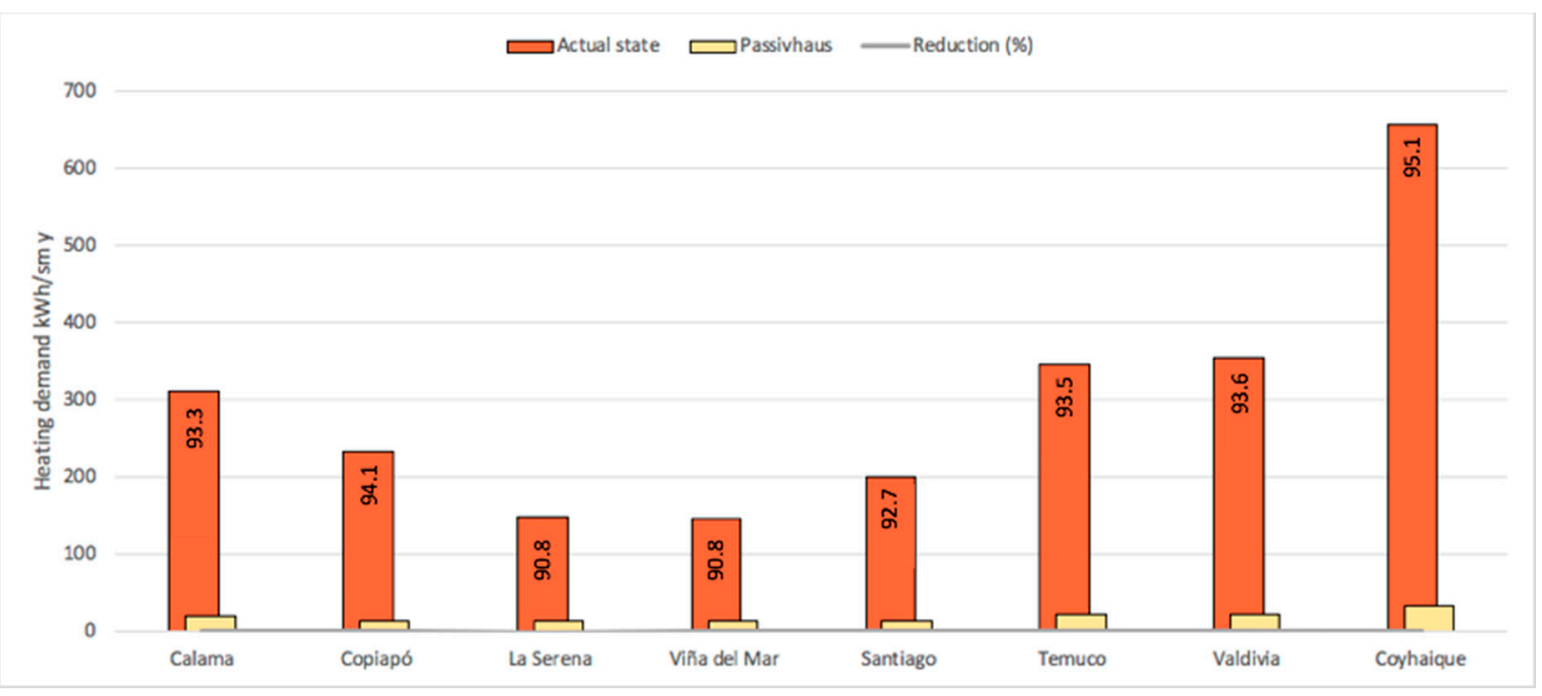

Figure 3. The heating demand of the houses studied without and with energy improvements.

Energy loss was analyzed alongside the heating demand (Figure 4) to identify its source and to use this information when implementing a strategy to reduce energy demand.

Unusable heat gains

Exterior wall - exterior air

Roof / cover - outside air

Screed / floor slab / sanitary floor

Windows

Thermal bridges

Ventilation

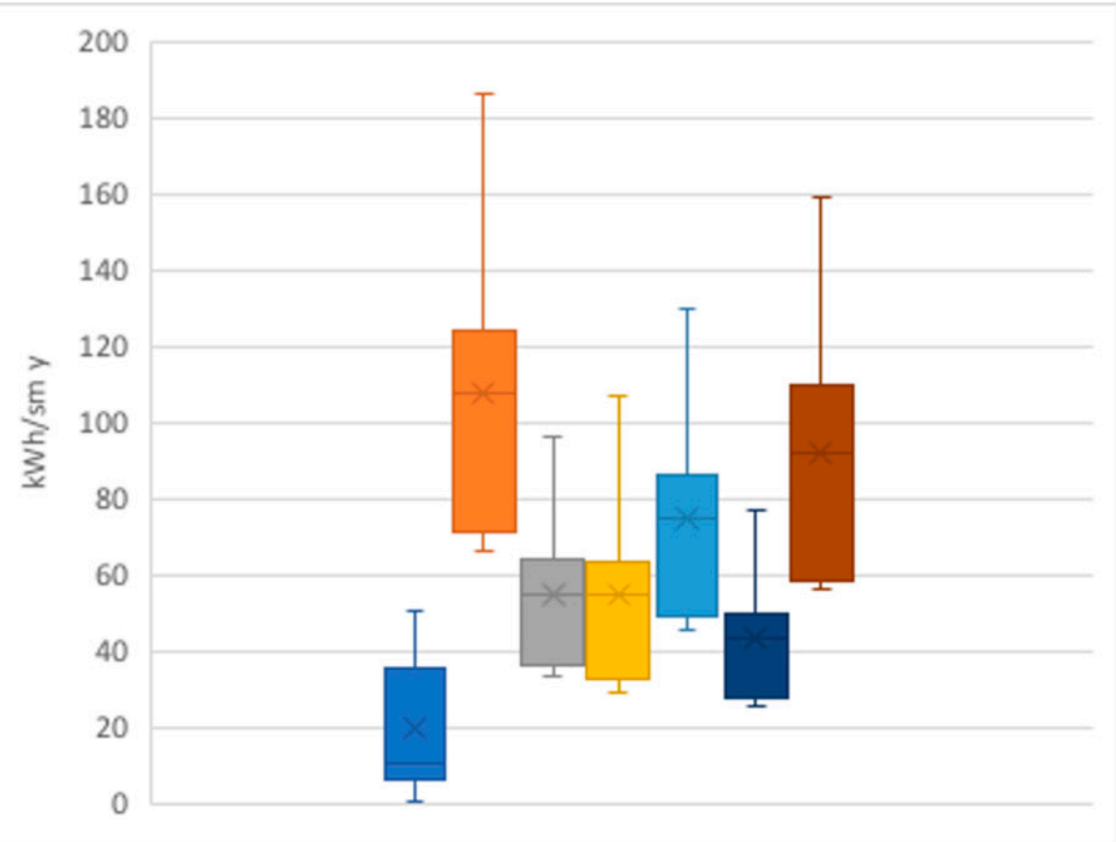

Figure 4. Energy loss through heating. 
Most energy loss occurs through exterior walls, then through ventilation, windows, roofs, floor slabs, thermal bridges and, finally, through non-usable heat gains.

\subsection{Financial Analysis}

The financial analysis helped to evaluate the investment increase when introducing $\mathrm{PH}$ and, therefore, to assess the feasibility of building PH housing. Table 8 shows the cost of implementing construction improvements. For insulation, the price refers to the square meter and centimeter thickness.

Table 8. Fixed cost estimation for materials and labor.

\begin{tabular}{cc}
\hline Element & Cost (Euros) \\
\hline Wall Insulation & $5.66 / \mathrm{m}^{2} / \mathrm{cm}$ \\
Roof Insulation & $0.59 / \mathrm{m}^{2} / \mathrm{cm}$ \\
Floor Insulation & $2.85 \mathrm{~m}^{2} / \mathrm{cm}$ \\
Double-Glazed Windows & $529.96 / \mathrm{m}^{2}$ \\
Triple-Glazed Windows & $566.55 / \mathrm{m}^{2}$ \\
Exterior Wall & $929.53 /$ unit \\
Ventilation with Heat Recovery & $1962.96 / \mathrm{system}$ \\
Airtightness Plate & $21.19 / \mathrm{m}^{2}$ \\
\hline
\end{tabular}
Source: [55]

Implementing PH resulted in an average increase of $37 \%$ in construction costs for the country. Windows and wall insulations were identified as the highest costs (Figure 5), at $10 \%$ and $8 \%$, respectively. In second place, floor insulation and ventilation experienced an investment increase of 3\% each, followed by airtightness at $2 \%$ and roof insulation at $1 \%$.

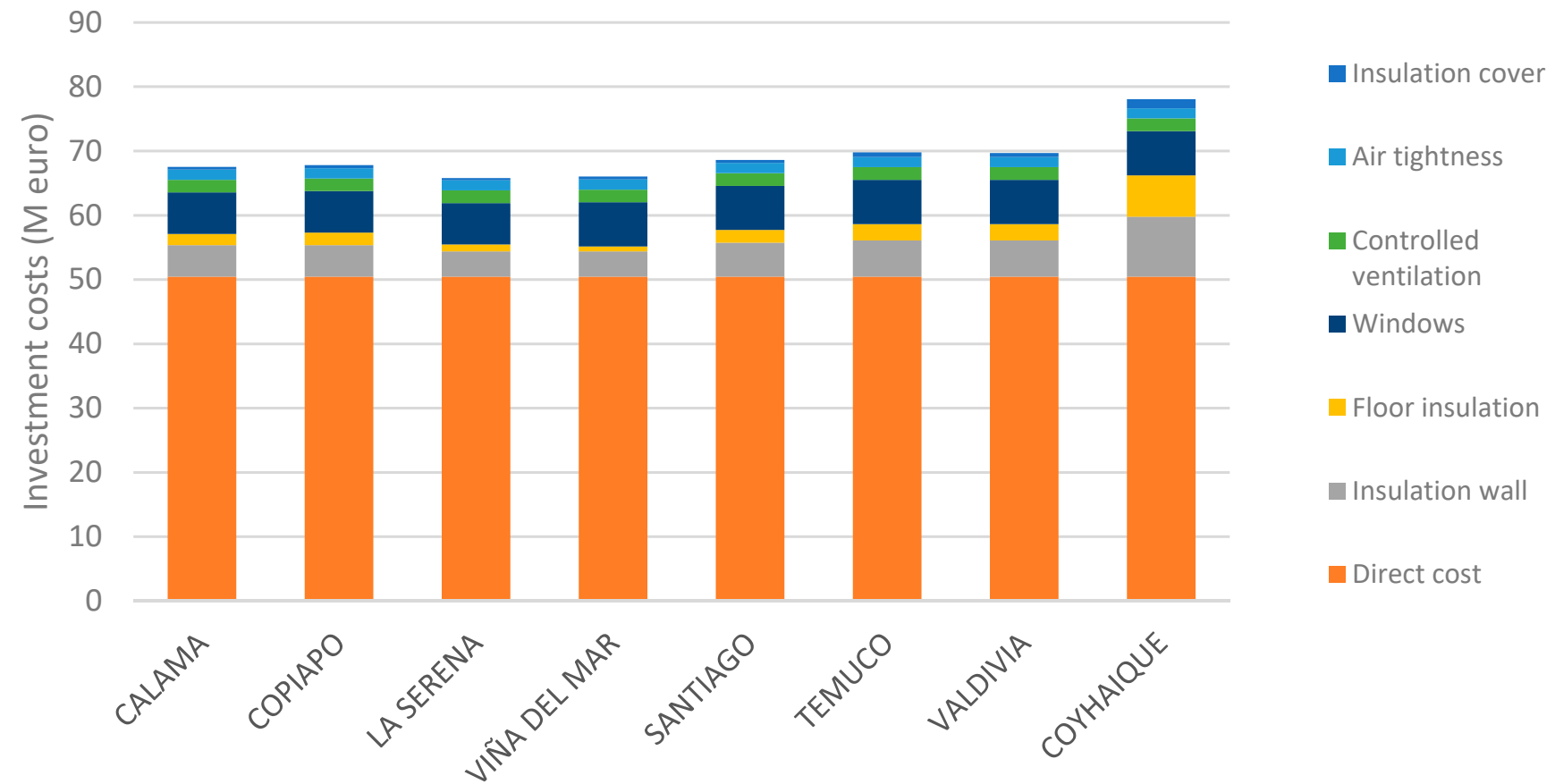

Figure 5. Investment costs for the case studies with reference to the type of improvement.

The identified PH investment differential is significantly higher than the international context, which indicates an increase between $8 \%$ and $15 \%[23,24]$. However, it is still amortized within a reasonable period in consideration of the building's lifespan. In the case of Chilean housing, the average amortization is 11 years (Table 9), making it more feasible to implement $\mathrm{PH}$ in the north of the country (6.8 years) than in the south (19.8 years). 
Table 9. The investment return period for the studies cases.

\begin{tabular}{ccc}
\hline City & Investment Increase (\%) & Amortization (Years) \\
\hline Calama & 33.85 & 6.8 \\
Copiapó & 34.38 & 8.7 \\
La Serena & 30.43 & 12.0 \\
Viña del Mar & 30.92 & 12.6 \\
Santiago & 35.99 & 10.5 \\
Temuco & 38.36 & 19.8 \\
Valdivia & 38.16 & 19.5 \\
Coyhaique & 54.77 & 16.0 \\
Average & 37.11 & 11.0 \\
\hline
\end{tabular}

Nonetheless, savings on energy bills over the years make PH convenient throughout Chile. The PH amortization average in Chile (Figure 6) indicates that savings made after 11 years of investment recovery correspond to more than $100 \%$ of the initial investment. Furthermore, this analysis does not consider the costs associated with house maintenance (which, in Chile, vary between 15\% and 25\%) and related to building quality deficiencies [56]. These considerations would increase the savings provided by $\mathrm{PH}$ housing.

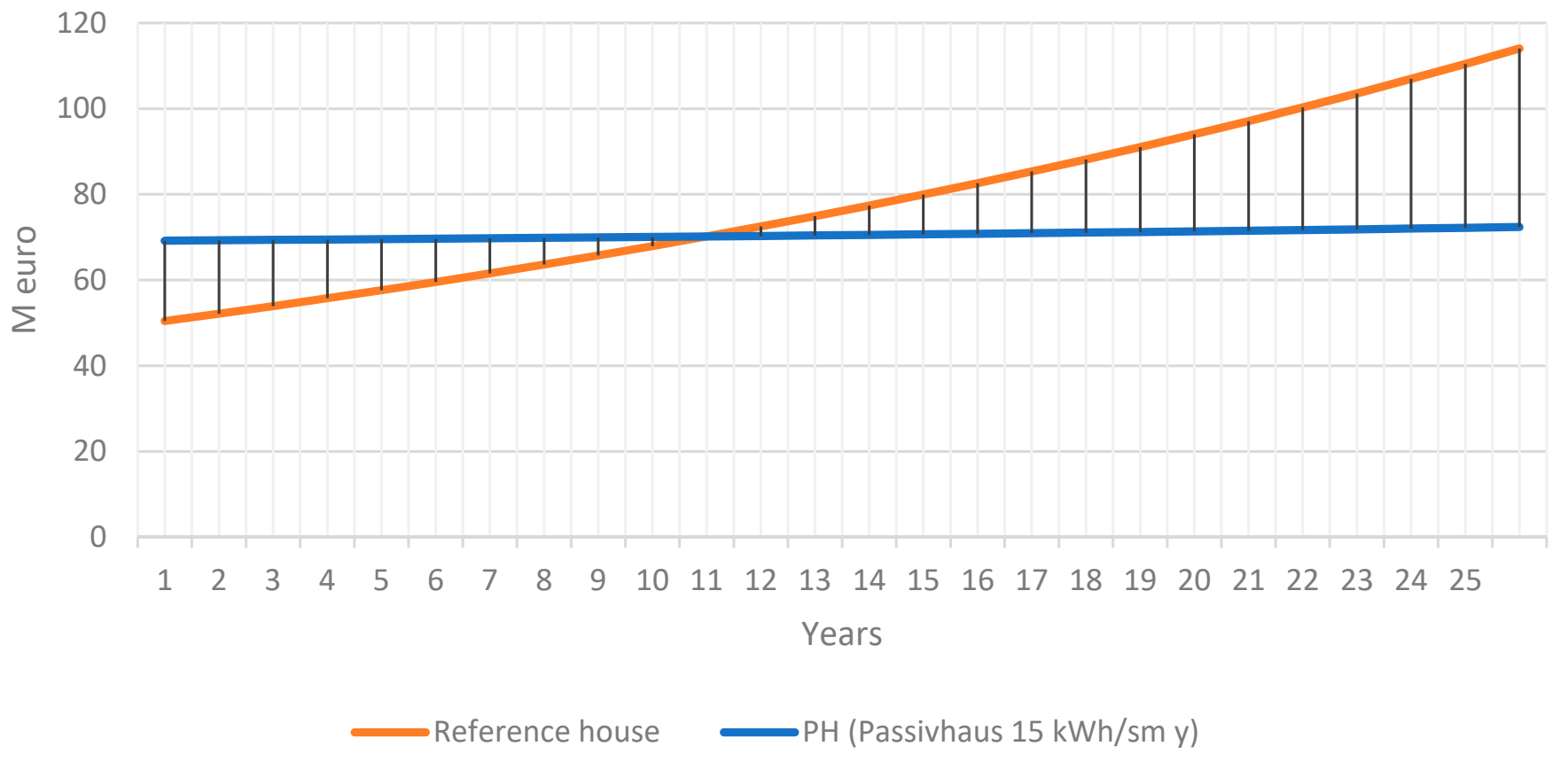

Figure 6. Average investment return period in Chile.

\subsection{Environmental Analysis}

The environmental analysis of this research is based on two indicators: primary energy and $\mathrm{CO}_{2}$ emission. Primary energy is the energy consumed by a house (heating use, refrigeration, domestic hot water, and lighting) plus storage and distribution energy. Energy consumption is defined as energy demand multiplied by a facility's efficiency factor. In this context, the savings noted in this research (Figure 7) as resulting from incorporating the $\mathrm{PH}$ standard into Chile's housing are 32\% (country average). These savings are significantly noticeable in the south of the country, reaching $57 \%$.

This primary energy consumption entails equivalent $\mathrm{CO}_{2}$ emissions (Figure 8) that fluctuate similarly, leading us to obtain country-level average equivalent $\mathrm{CO}_{2}$ savings of $39 \%$ when implementing PH. Likewise, savings are more noticeable in the south of the country, reaching $65 \%$. 


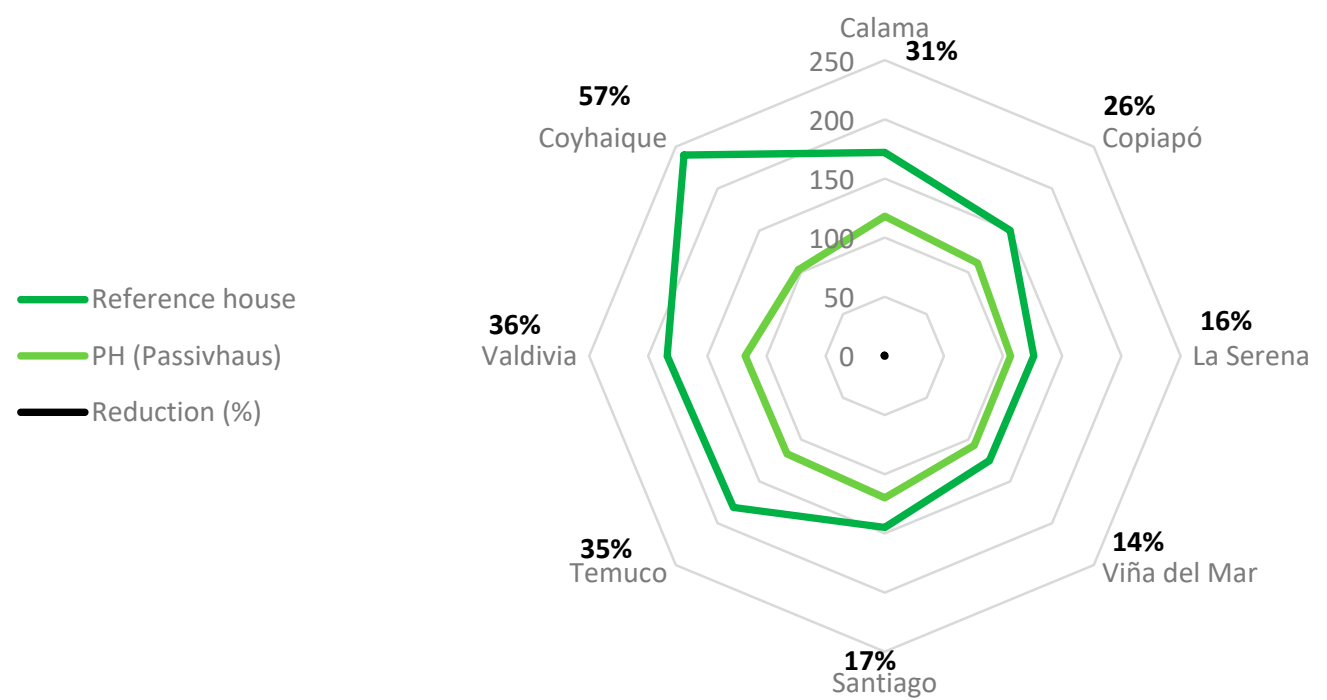

Figure 7. The primary housing energy under study and PH.

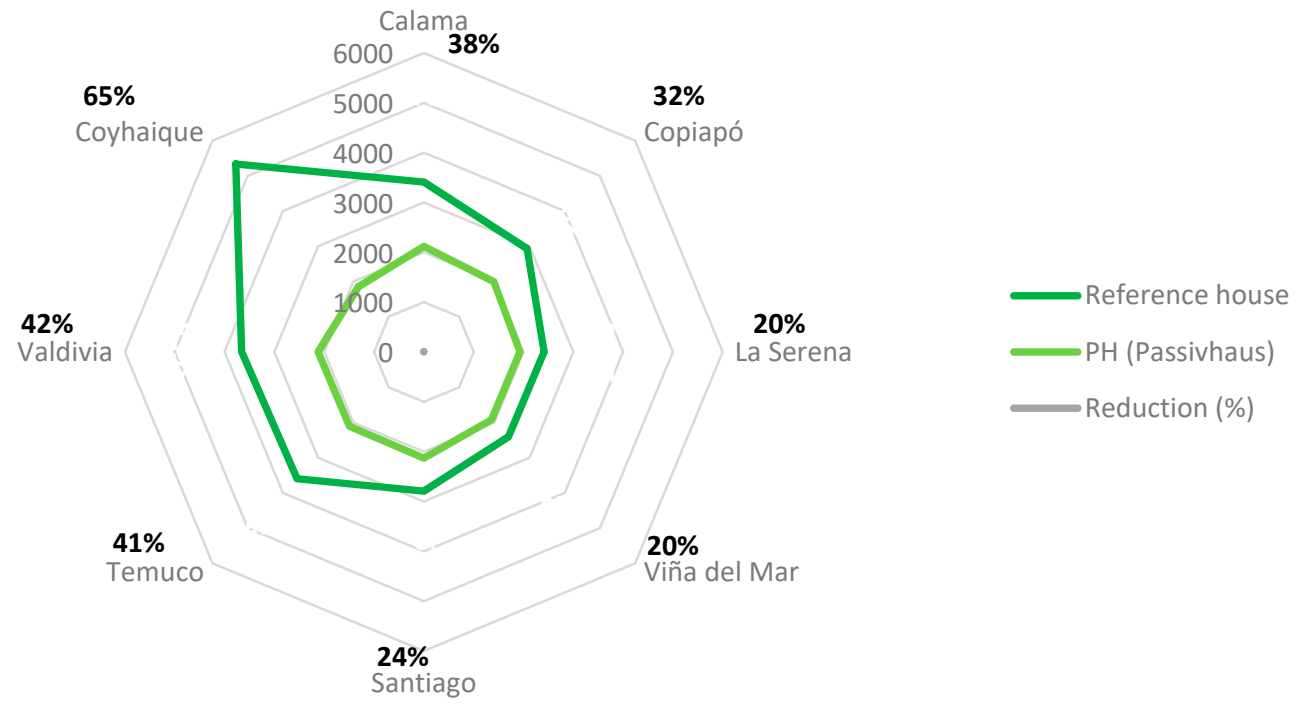

Figure 8. Equivalent $\mathrm{CO}_{2}$ of the housing under study and $\mathrm{PH}$.

\section{Discussion}

When assessing the reference housing in terms of energy, none of the eight studied cities comply with $\mathrm{PH}$ requirements. Heating energy demand varies from 147.3 to $657.9 \mathrm{kWh} / \mathrm{m}^{2}$ per year, far from the required standard of $15 \mathrm{kWh} / \mathrm{m}^{2}$ per year. This difference occurs due to the current building regulations in Chile, which, as studies indicate, display significant disparities regarding key concepts that directly affect a building's energy performance. Infiltration is one of the essential unsolved concepts in Chilean regulation. In Chile, the average infiltration index is 12.9 air changes per hour [7], in contrast with the 3 air changes per hour required in most European countries and the 0.6 air changes per hour required by $\mathrm{PH}$. The air changes per hour identified for the housing under study are 19 times greater than those contemplated by $\mathrm{PH}$.

As with infiltrations, most of Chile's housing has deficient thermal envelope elements since the vast majority was built before the implementation of the regulations in 2000, and another significant percentage was built between 2007 and 2013, which resulted in elements of glazed and non-glazed areas being inferior to those required by $\mathrm{PH}$.

This study identified a thermal transmittance $U$ value for walls nine times higher than $\mathrm{PH}$ requirements, a window $\mathrm{U}$ value six times higher, and a roof $\mathrm{U}$ value five times higher 
than that identified in international studies [22,57]. Flooring in Chile is not the subject of thermal restrictions.

The significant differences noted in each of the thermal envelope elements and the infiltration levels are responsible for Chile's excessive housing energy demand.

On the financial side, international studies acknowledge that the additional contribution of incorporating the $\mathrm{PH}$ standard fluctuates between an additional $8 \%$ to $15 \%[23,24]$. On the other hand, in Chile, the incorporation of the PH standard would increase by an average of $37 \%$. The reason for this difference is similar to the one found regarding energy. In European countries where price fluctuations are not significant, regulations control aspects that are not regulated in Chile and, therefore, the price per square meter is higher. Consequently, the additional contribution for compliance with $\mathrm{PH}$ is lower.

Regarding investment turnover, the country average is 11 years when considering energy savings and fuel inflation.

On the environmental side, incorporating the PH standard allows for a countrywide decrease of $93 \%$ in heating energy demand, which is in accordance with the experience internationally $[22,24]$.

\section{Conclusions}

The Passivhaus standard refers to a building type designed to take advantage of the climate context in each specific zone. Theoretically, its incorporation is viable in any climate type, being more feasible in certain climates depending on a country's economic and regulatory contexts.

In Chile's case, the housing under study is well above the required PH values regardless of the climate zone. No overheating was identified in terms of refrigeration demand for the housing typology in the assessed climate conditions. Therefore, there is no need to incorporate active elements to cool the building in any season. This is due to the controlled ventilation machine with heat recovery (considered a passive element in this study) which conditions the air (both hot and cold). In Santiago's case, a bypass system is necessary for the summer to prevent the ventilation machine from overheating.

When implementing the PH standard, special caution is needed to not overinsulate areas with high solar radiation as this may cause overheating of the house, generating discomfort in the summer. This, in turn, would result in noncompliance with the standard's requirements.

On the other hand, the incorporated strategies and technologies go hand-in-hand with excellent execution. As this standard has minimal energy demands, the smallest error in execution will result in unnecessary energy loss, which may pass in a regular building, but could result in noncompliance with PH criteria in housing with these characteristics.

It was only possible to achieve the $\mathrm{PH}$ standard in each analyzed climate by incorporating passive elements, which are considered the pillars of this standard. This study focuses on the exclusive implementation of passive elements. However, it is necessary to consider each case to evaluate if it is more convenient (and, most of the time, it is) to incorporate active auxiliary systems that contribute to indoor comfort.

Furthermore, applying PH to the Chilean context promotes a reduction in GHG emissions, which aligns with Chile's goals for 2030.

It was shown that the PH standard is feasible for Chilean climates at a high cost (compared to other international contexts). However, it can be amortized within a reasonable period given that a building's lifespan is at least 50 years. The energy strategies result in energy cost reductions and offer residents spaces of higher quality with more stable and controlled levels of thermal comfort.

Finally, this study also demonstrates the feasibility of implementing Passivhaus in the different climatic zones of Chile with the current construction systems that are in place throughout the country. However, it is necessary to continue exploring thermomodernization solutions through parametric studies and by training workers who can execute them correctly in order to meet the design requirements. 
Author Contributions: Methodology, C.B.-O. and J.M.G.-S.; validation, C.V.-U. and F.S.-D.; formal analysis, C.B.-O. and J.M.G.-S.; investigation, J.M.G.-S.; resources, J.M.G.-S. and C.V.-U.; data curation, C.B.-O.; writing-original draft preparation, C.B.-O. and J.M.G.-S.; writing-review and editing, C.V.-U. and F.S.-D.; visualization, C.B.-O.; supervision, J.M.G.-S. All authors have read and agreed to the published version of the manuscript.

Funding: This research received no external funding.

Institutional Review Board Statement: Not applicable.

Informed Consent Statement: Not applicable.

Data Availability Statement: The data presented in this study are available on request from the corresponding author.

Acknowledgments: The authors would like to thank the Barcelona School of Building ConstructionUPC, the Department of Architecture Technology-EPSEB-UPC; the School of Civil Construction, Faculty of Engineering, Pontifical Catholic University of Chile; and the School of Construction Engineering, Faculty of Sciences, Major University.

Conflicts of Interest: The authors declare no conflict of interest.

\section{References}

1. IPCC Climate Change 2014: Synthesis Report. Available online: https://www.ipcc.ch/site/assets/uploads/2018/05/SYR_AR5 _FINAL_full_wcover.pdf (accessed on 9 April 2020).

2. International Energy Agency Buildings-A Source of Enormous Untapped Efficiency Potential. Available online: https://www. iea.org/topics/buildings (accessed on 15 July 2020).

3. Nejat, P.; Jomehzadeh, F.; Taheri, M.M.; Gohari, M.; Muhd, M.Z. A global review of energy consumption, $\mathrm{CO}_{2}$ emissions and policy in the residential sector (with an overview of the top ten $\mathrm{CO}_{2}$ emitting countries). Renew. Sustain. Energy Rev. 2015, 43, 843-862. [CrossRef]

4. Global Alliance for Buildings and Construction towards Low-Ghg and Resilient Buildings. Available online: https://globalabc. org/sites/default/ files/2020-03/GABC_Global_Roadmap_Website.pdf (accessed on 15 July 2020).

5. Wassouf, M. De la Casa Pasiva al Estándar Passivhaus, la Arquitectura Pasiva en Climas Cálidos, 1st ed.; Gili, G., Ed.; Michael Wassouf: Barcelona, Spain, 2014; Available online: https:/ /www.amazon.com/casa-pasiva-est\%C3\%A1ndar-Passivhaus-arquitectura/dp/ 8425224527 (accessed on 7 January 2021).

6. Rodríguez-Soria, B.; Domínguez-Hernández, J.; Pérez-Bella, J.M.; Del Coz-Díaz, J.J. Review of international regulations governing the thermal insulation requirements of residential buildings and the harmonization of envelope energy loss. Renew. Sustain. Energy Rev. 2014, 34, 78-90. [CrossRef]

7. Ariel Bobadilla, M.; Muriel Díaz, C.; Rodrigo Figueroa, S.; Roberto Arriagada, B. Proposal of acceptable air tightness classes for buildings in Chile. Rev. Constr. 2014, 13, 15-23. [CrossRef]

8. Damico, F.C.; Alvarado, R.G.; Kelly, M.T.; Oyola, O.E.; Oyola, O.E.; Diaz, M. Análisis energético de las viviendas del centro-sur de Chile. Arquiteturarevista 2012, 8, 62-75. [CrossRef]

9. Scofield, J.H. Do LEED-certified buildings save energy? Not really . . . . Energy Build. 2009, 1386-1390. [CrossRef]

10. Newsham, G.R.; Mancini, S.; Birt, B.J. Do LEED-certified buildings save energy? Yes, but ... . Energy Build. 2009, 41, 897-905. [CrossRef]

11. Ministerio de Vivienda y Urbanismo. Ordenanza General de Urbanismo y Construcciones; Más que un Techo: Santiago de Chile, Chile, 2020; p. 444. Available online: https:/ / www.minvu.cl/elementos-tecnicos/decretos/d-s-n47-1992-ordenanza-general-deurbanismo-y-construccione/ (accessed on 7 January 2021).

12. Tubelo, R.C.S.; Rodrigues, L.T.; Gillott, M. A comparative study of the Brazilian energy labelling system and the passivhaus standard for housing. Buildings 2014, 4, 207-221. [CrossRef]

13. Sadineni, S.B.; Madala, S.; Boehm, R.F. Passive building energy savings: A review of building envelope components. Renew. Sustain. Energy Rev. 2011, 15, 3617-3631. [CrossRef]

14. CTE Código Técnico de la Edificación. Available online: https://www.codigotecnico.org/DocumentosCTE/DocumentosCTE. html (accessed on 7 January 2021).

15. Zhao, J.; Carter, K. Do passive houses need passive people? Evaluating the active occupancy of Passivhaus homes in the United Kingdom. Energy Res. Soc. Sci. 2020, 64, 101448. [CrossRef]

16. Tabatabaei Sameni, S.M.; Gaterell, M.; Montazami, A.; Ahmed, A. Overheating investigation 224 in UK social housing flats built to the Passivhaus standard. Build. Environ. 2015, 92, 222-235. [CrossRef]

17. Mitchell, R.; Natarajan, S. UK Passivhaus and the energy performance gap. Energy Build. 2020, 224, 110240. [CrossRef]

18. Persson, J.; Grönkvist, S. Drivers for and barriers to low-energy buildings in Sweden. J. Clean. Prod. 2015, 109, 296-304. [CrossRef]

19. Directiva 2010/31/Ue del Parlamento Europeo y del Consejo. Available online: https://www.boe.es/doue/2010/153/L00013-0 0035.pdf (accessed on 7 January 2021). 
20. Dequaire, X. Passivhaus as a low-energy building standard: Contribution to a typology. Energy Effic. 2012, 5, 377-391. [CrossRef]

21. Feist, W.; Schnieders, J.; Dorer, V.; Haas, A. Re-inventing air heating: Convenient and comfortable within the frame of the Passive House concept. Energy Build. 2005, 37, 1186-1203. [CrossRef]

22. Schnieders, J.; Hermelink, A. CEPHEUS results: Measurements and occupants' satisfaction 8 provide evidence for Passive Houses being an option for sustainable building. Energy Policy 2006, 34, 151-171. [CrossRef]

23. Saldaña-Márquez, H.; Gómez-Soberón, J.M.; Arredondo-Rea, S.P.; Almaral-Sánchez, J.L.; Gómez-Soberón, M.C.; Rosell-Balada, G. The passivhaus standard in the mediterranean climate: Evaluation, comparison and profitability. J. Green Build. 2015, 10, 55-72. [CrossRef]

24. Schnieders, J.; Feist, W.; Rongen, L. Passive Houses for different climate zones. Energy Build. 2015, 105, 71-87. [CrossRef]

25. Passive House Institute Project documentation. Available online: https://cms.passivehouse.com/media/persons/ buildingdocumentation/documentation/ph_Huenchunir_Santiago_2133.pdf (accessed on 30 June 2020).

26. Passive House Institute Passive House Database. Available online: https://passivehouse-database.org/index.php?lang=en (accessed on 1 June 2020).

27. Kyropoulou, M.; Hernandez, A.E. The why house rethinking the passivhaus standard in a subtropical climate. In Proceedings of the 28th International PLEA Conference Sustainable Architecture Design Opportunities, Limits \& Needs towards an Environmentally Responsible Architecture, Lima, Peru, 7-9 November 2012.

28. Brew, J.S. Achieving Passivhaus standard in North America: Lessons learned. ASHRAE Trans. 2011, 117, 51-58.

29. Sangiorgio, A.; Brambilla, A. Sustainable buildings need sustainable design processes: The case of the Woodside Building for Technology and Design, the first University building in Australia to aim for the Passivhaus certification. IOP Conf. Ser. Earth Environ. Sci. 2020, 588, 022072. [CrossRef]

30. Sigalingging, R.C.; Chow, D.; Sharples, S. Applying the Passivhaus standard to a terraced house in a hot and humid tropical climate-Evaluation of comfort and energy performance. Build. Serv. Eng. Res. Technol. 2020, 41, 247-260. [CrossRef]

31. Liu, C.; Mohammadpourkarbasi, H.; Sharples, S. Evaluating the potential energy savings of retrofitting low-rise suburban dwellings towards the Passivhaus EnerPHit standard in a hot summer/cold winter region of China. Energy Build. 2020, 231, 110555. [CrossRef]

32. Badescu, V.; Rotar, N.; Budea, S. Simple rule to estimate the changes in the heating demand of the German Passivhaus when accomodating the climate of Eastern Europe. Sustain. Cities Soc. 2016, 24, 20-32. [CrossRef]

33. Udrea, I.; Badescu, V. Usage of solar shading devices to improve the thermal comfort in summer in a Romanian PassivHaus. Simulation 2020, 96, 471-486. [CrossRef]

34. Passive House Institute Passive House Planning Package (PHPP). Available online: https://passivehouse.com/04_phpp/04 _phpp.htm (accessed on 9 July 2020).

35. Johnston, D.; Siddall, M. The building fabric thermal performance of passivhaus dwellings-Does it do what it says on the tin? Sustainability 2016, 8, 97. [CrossRef]

36. Passive House Institute Criteria for the Passive House, EnerPHit and PHI Low Energy BuildingStandard. Available online: https:/ / passiv.de/downloads/03_building_criteria_en.pdf (accessed on 9 July 2020).

37. Sanhueza-Durán, F.; Gómez-Soberón, J.M.; Valderrama-Ulloa, C.; Ossio, F. A comparison of energy efficiency certification in housing: A study of the Chilean and spanish cases. Sustainability 2019, 11, 4771. [CrossRef]

38. CITEC UBB. DECON UC Manual de Hermeticidad al Aire de Edificaciones. Available online: http:/ / construccionsustentable.uc. cl/images/Documentos/Manual_de_hermeticidad_al_aire_de_edificaciones.pdf (accessed on 20 July 2020).

39. CChC Manual Acondicionamiento Térmico. Available online: https://www.cchc.cl/centro-de-informacion/publicaciones/ publicaciones-manuales-tecnicos/manual-de-acondicionamiento-termico-criterios-de-intervencion (accessed on 16 July 2020).

40. Rouault, F.; Ossio, F.; González-Levín, P.; Meza, F. Impact of Climate Change on the Energy Needs of Houses in Chile. Sustainability 2019, 11, 7068. [CrossRef]

41. Farías, F.; Jadrijevic, M. National Action Plan on Climate Change. Government of Chile, Ministry of the Environment, Santiago de Chile. 2017, p. 260. Available online: https://mma.gob.cl/wp-content/uploads/2018/06/PANCCv3-19-10-baja.pdf (accessed on 7 January 2021).

42. Minister Commission for Housing and Urban Studies. Building Statistics. Government of Chile, Ministry of Housing and Informative Urbanism, Santiago de Chile. 2018. Available online: https://www.minvu.cl/wp-content/uploads/2019/07/ Informativo-Estad\%C3\%ADstico-de-Edificaci\%C3\%B3n-a-Sep-2018.pdf (accessed on 7 January 2021).

43. Cámara Chilena de la Construcción Indicador: Inversión en Construcción. Available online: https://www.cchc.cl/centro-deinformacion/indicadores/inversion-en-construccion (accessed on 15 February 2020).

44. INE Censo de Población y Vivienda. Available online: https://www.ine.cl/estadisticas/sociales/censos-de-poblacion-yvivienda/poblacion-y-vivienda (accessed on 15 February 2020).

45. Ministerio de Vivienda y Urbanismo Listados Técnicos Oficiales. Available online: http://minvuhistorico.minvu.cl/opensite_20 070611111640.aspx (accessed on 15 July 2020).

46. Hatt, T.; Saelzer, G.; Hempel, R.; Gerber, A. High indoor comfort and very low energy consumption through the implementation of the passive house standard in Chile. Rev. Constr. 2012, 11, 123-134. [CrossRef]

47. Martinez-Soto, A.; Saldias-Lagos, Y.; Marincioni, V.; Nix, E. Affordable, energy-efficient housing design for chile: Achieving passivhaus standard with the chilean state housing subsidy. Appl. Sci. 2020, 10, 7390. [CrossRef] 
48. Energía, C.N. de Balance Nacional de Energía. Available online: http://energiaabierta.cl/visualizaciones/balance-de-energia/ (accessed on 9 April 2020).

49. SERNAC Venta de leña y Carbon. Available online: https://www.sernac.cl/portal/619/w3-article-21996.html\#publicaciones (accessed on 1 May 2020).

50. CNE Precio Medio de Mercado. Available online: https:/ /www.cne.cl/precio-medio-de-mercado-2/ (accessed on 25 April 2020).

51. National Institute of Standardization. Architecture and Construction-Housing Climate Zoning for Chile and Recommendations for Architectural Design. Government of Chile, Ed. 2008. Available online: https://seigrapa.weebly.com/uploads/1/1/8/2/11 828201/nch1079-1977.pdf (accessed on 7 January 2021).

52. MINVU Manual de Aplicación de la Reglamentación Térmica. Available online: http://admminvuv57.minvu.cl/opensite_2007 0417155724.aspx (accessed on 20 July 2020).

53. Ministerio del Medio Ambiente Quinto Reporte del Estado del Medioambiente. Available online: https://sinia.mma.gob.cl/ quinto-reporte-del-estado-del-medio-ambiente/ (accessed on 20 July 2020).

54. IPHA Climate Data Tool. Available online: https://passipedia.org/planning/calculating_energy_efficiency/phpp_-_the_ passive_house_planning_package/climate_data_tool (accessed on 7 July 2020).

55. CYPE Ingenieros Generador de Precios. Available online: http://www.generadordeprecios.info/obra_nueva/L_Carpinteria_ _cerrajeria_vidrios_y_/Vidrios/Doble_acristalamiento/Doble_acristalamiento.html\#gsc.tab=0 (accessed on 9 May 2020).

56. Ramírez, V.; Serpell, A. Certificación de la calidad de viviendas en Chile: Análisis comparativo con sistemas internacionales. Rev. Construcción 2012, 11, 134-144. [CrossRef]

57. Schnieders, J. CEPHEUS - Measurement results from more than 100 dwelling units in passive houses. Time to Turn Down Energy Demand: Proceedings of the 2003 ECEEE Summer Study. 2003, pp. 341-351. Available online: https://www.eceee.org/static/ media/uploads/site-2/library/conference_proceedings/eceee_Summer_Studies/2003c/Panel_2/2047schnieders/paper.pdf (accessed on 7 January 2021). 